\title{
Monoclonal antibodies against Streptococcus pneumoniae detect epitopes on eubacterial ribosomal proteins L7/L12 and on streptococcal elongation factor Ts
}

\author{
Jan Kolberg, ${ }^{1}$ E. Arne Høiby, ${ }^{2}$ Rodrigo Lopez ${ }^{3}$ and Knut Sletten ${ }^{3}$
}

Author for correspondence: Jan Kolberg. Tel: +472204 2660. Fax: +4722353605.

1,2 National Institute of
Public Health,
Departments of
Vaccinology' and
Bacteriology', PO Box
4404 Torshov, N-0403
Oslo, Norway
3 Biotechnology Centre of
Oslo and Department of
Biochemistry, University
of Oslo, Gaustadalléen
21, N-0371 Oslo, Norway

\begin{abstract}
Two monoclonal antibodies (mAbs) designated 144, H-3 (IgG2a) and 218,C-5 (IgM) were produced after immunization of mice with two different heattreated and sonicated pneumococcal strains. Western blotting, with solubilized proteins from different bacterial genera and from mammalian lymphocytes, showed that both mAbs reacted with a protein of approximately $12 \mathrm{kDa}$ in all 66 strains of eubacteria examined, representing 27 different species. The $12 \mathrm{kDa}$ protein was isolated by immunoaffinity chromatography. Subsequent preparative Western blotting enabled $\mathbf{N}$-terminal amino acid sequence analysis by microsequencing. A high degree of amino acid sequence similarity with eubacterial ribosomal proteins L7/L12 was demonstrated. One of the mAbs $(144, \mathrm{H}-3)$ also cross-reacted in Western blotting with a $43 \mathrm{kDa}$ protein, but only from streptococci. The $43 \mathrm{kDa}$ protein carrying the common streptococcal epitope was isolated and sequenced in the $\mathbf{N}$-terminal region. A high degree of amino acid sequence identity was found to elongation factor Ts from Escherichia coli.
\end{abstract}

Keywords: monoclonal antibodies, eubacteria, Streptococcus pneumoniae, ribosomal protein $\mathrm{L} 7 / \mathrm{L} 12$, elongation factor Ts

\section{INTRODUCTION}

Infections caused by Streptococcus pneumoniae still remain a major cause of morbidity and mortality throughout the world, in particular among infants and elderly people. Capsular polysaccharides are essential virulence determinants and are used for classification of pneumococci into 90 types (Lund \& Henrichsen, 1978; Henrichsen, 1995). This organism also has a common cell wall polysaccharide of which phosphorylcholine is the immunologically dominant epitope. When mice are immunized with pneumococci, one of the most prominent antibody responses is to this phosphorylcholine determinant (McDaniel et al., 1986). This may be the reason why few reports on monoclonal antibodies

\footnotetext{
Abbreviations: DOC, sodium deoxycholate; EF-Ts, elongation factor Ts. The EMBL accession numbers for the amino acid sequences of ribosomal L7/L12 protein from Streptococcus pneumoniae and Neisseria meningitidis reported in this paper are P80714 and P80716, respectively. The accession number for the sequence of the elongation factor from $S$. pneumoniae is P80715.
}

(mAbs) against pneumococcal capsular polysaccharides and protein antigens are published. This observation may also explain why only a few proteins from this Gram-positive bacterium have been characterized (Tuomanen et al., 1995), even though proteins may contribute to the pathogenesis of pneumococcal infections. Furthermore, increased knowledge of common pneumococcal proteins might also be useful in the development of new vaccines.

We have immunized mice with different clinical isolates of S. pneumoniae. After fusion of spleen cells with myeloma cells the supernatant fluids were first screened with the strain used for immunization and purified cell wall polysaccharides. Antibodies that reacted with the bacterial strain used as immunogen, but not with the cell wall polysaccharides, were then tested by Western blotting to select those reacting with epitopes expressed on proteins. From these experiments we report two $\mathrm{mAbs}$ that recognize highly conserved epitopes on bacterial L7/L12 ribosomal proteins. The $\mathrm{L} 7 / \mathrm{L} 12$ ribosomal proteins are among the most investigated components of the prokaryotic ribosomes, but there has, up 
to now, only been one report on mAbs against these proteins (Sommer et al., 1985). The mAbs cross-reacted with $\mathrm{L} 7 / \mathrm{L} 12$ ribosomal proteins of other eubacteria, indicating a common conserved epitope as the reactive motif.

\section{METHODS}

Bacterial strains. The bacteria examined are described in Table 1. Most of the strains were human clinical isolates, but some were obtained from the American Type Culture Collection (ATCC). Pneumococcal strains of the different capsular types included in the 23-valent vaccine (Pneumovax; Merck, Sharp \& Dohme) were typed by the capsular reaction test with rabbit antisera purchased from Statens Seruminstitut (Copenhagen, Denmark). Differentiation of types within groups was carried out at Statens Seruminstitut. Statens Seruminstitut also supplied us with Streptococcus suis type 8, strain 14636, and Escherichia coli strain U5/91. Mycobacterium leprae was obtained from $\operatorname{Dr} \mathrm{M}$. J. Colston (National Institute for Medical Research, London, UK). Mycobacterium bovis, strain Myc 14323, was received from Rijksinstituut voor Volksgezondheid en Mileuhygiene (Bilthoven, The Netherlands). Archaeoglobus fulgidus strain VC-16 (Steiter, 1988) was obtained from Dr Torleif Lien (Institute of Microbiology, University of Bergen, Bergen, Norway).

Polysaccharides. Pneumococcal capsular polysaccharides were obtained from ATCC. Purified cell wall polysaccharides from S. pneumoniae were a gift from Dr Jørgen Henrichsen (Statens Seruminstitut, Copenhagen).

Production of mAbs $144, \mathrm{H}-3$ and 218,C-5. Heat-treated $\left(30 \mathrm{~min}\right.$ at $60^{\circ} \mathrm{C}$ ), sonicated pneumococcal strains of capsular types 8 and $23 \mathrm{~F}$ were used as immunogens. The type-8-derived antigen was inoculated into BALB/c mice and resulted in $\mathrm{mAb}$ $144, \mathrm{H}-3$. mAb 218, C-5 was generated by immunization of $\mathrm{C} 57 \mathrm{Bl}$ mice with the antigen from the type $23 \mathrm{~F}$ strain.

Six-week-old BALB/c and C57Bl mice were immunized with sonicated bacterial suspensions containing $50 \mathrm{\mu g}$ protein in $0.25 \mathrm{ml}$ PBS mixed with $0.25 \mathrm{ml}$ Freund's incomplete adjuvant followed by a booster injection 2 weeks later with the same mixture. Four months later, and $7 \mathrm{~d}$ before fusion, one BALB/c mouse was injected with the above mentioned immunogen, followed by $50 \mu \mathrm{g}$ protein in PBS on days 4 and 3 prior to fusion. Four weeks after the primary injections and 3 $\mathrm{d}$ prior to fusion, one $\mathrm{C} 57 \mathrm{Bl}$ mouse was injected intravenously with $50 \mu \mathrm{g}$ protein in PBS. All injections, except the last one to the C57Bl mouse, were given intraperitoneally. Spleen cells from the two mouse strains were fused with NSO myeloma cells by standard methods (Fazekas de St Groth \& Scheidegger, 1980; Lane, 1985). Mouse splenocytes were used as feeder cells.

Hybridoma supernatant fluids were screened in an ELISA (see below) against the immunizing pneumococcal strain and against cell wall polysaccharides. Those which reacted only with sonicated and heat-treated pneumococci $(30 \mathrm{~min}$ at $60^{\circ} \mathrm{C}$ ) were checked by Western blotting with bacterial proteins from the immunizing strain and from Haemophilus influenzae, originally used as a negative control. Hybridoma cells were cloned by limiting dilution with Hybridoma Enhancing Supplement (Sigma) instead of feeder cells. Hybridoma cells were expanded and cultured in the peritoneal cavities of Pristane-primed mice to obtain ascitic fluid. Isotyping of mAbs in hybridoma supernatant fluids was performed in an ELISA with heat-treated $\left(30 \mathrm{~min}\right.$ at $60^{\circ} \mathrm{C}$ ) and sonicated pneumococci as coating antigen (see below) using a kit from Zymed Laboratories.

Protein assay. For determination of protein concentrations, aliquots of the bacteria were dissolved in $0.5 \mathrm{M} \mathrm{NaOH}$. The Lowry method was used, with BSA as standard.

ELISA. Flat-bottomed microtitre plates (MaxiSorp, Nunc) were coated overnight at $4{ }^{\circ} \mathrm{C}$ with heat-treated $(30 \mathrm{~min}$ at $\left.60^{\circ} \mathrm{C}\right)$ and sonicated pneumococci $\left(25 \mu \mathrm{g}\right.$ protein $\left.\mathrm{ml}^{-1}\right)$ in PBS with $0.02 \%$ sodium azide, $50 \mu \mathrm{l}$ per well. Hybridoma supernatant fluids were added in $50 \mu \mathrm{l}$ aliquots and incubated for $2 \mathrm{~h}$ at $37^{\circ} \mathrm{C}$. Alkaline-phosphatase-conjugated goat antimouse Ig (Sigma) was used at a $1 / 2000$ dilution in PBS containing $3 \%$ BSA. $p$-Nitrophenyl phosphate was used as the substrate $\left[1 \mathrm{mg} \mathrm{ml}^{-1}\right.$ in $10 \%$ diethanolamine buffer $(\mathrm{pH} 9 \cdot 8)$ containing $5 \mathrm{mM} \mathrm{MgCl}$ ]. PBS plus Tween $20(0.05 \%)$ was used for the washes between each step (Kolberg et al., 1992).

SDSPAGE and immunoblotting. The bacterial suspensions in PBS were boiled for $5 \mathrm{~min}$ with sample buffer containing 2mercaptoethanol (Laemmli, 1970). In the case of the mycobacteria, the bacteria were first sonicated for $20 \mathrm{~min}$ in iced water and then boiled as for the other samples. Samples containing $7 \mu \mathrm{g}$ protein were placed in each well formed by a 15-tooth comb in a Bio-Rad Mini-Protean slab cell apparatus. SDS-PAGE was performed with stacking and separating gels containing 4 and $15 \%(\mathrm{w} / \mathrm{v})$ acrylamide, respectively. The separated proteins were electrotransferred to a nitrocellulose membrane (pore size $0.2 \mu \mathrm{m}$ ). To prevent non-specific binding of proteins, the membranes were incubated for $30 \mathrm{~min}$ in a blocking buffer consisting of $3 \%$ BSA in PBS. The mAbs were used as hybridoma supernatant fluids diluted (range $1 / 10$ $1 / 1000$ ) in blocking buffer. As secondary antibody, peroxidase-conjugated rabbit anti-mouse Ig was used (Dakopatts, dilution 1/1000). The immunostaining was performed with 3amino-9-ethylcarbazole and hydrogen peroxide in sodium acetate buffer ( $\mathrm{pH} 5 \cdot 0$ ). Rainbow protein molecular mass markers were obtained from Amersham. The protein content of the different organisms and cells, electroblotted to nitrocellulose membranes after SDS-PAGE, was controlled by protein staining with Amido black.

Cross-inhibition studies of mAb epitope specificity. Nitrocellulose membrane strips containing $S$. pneumoniae proteins separated by SDS-PAGE were blocked with $3 \%$ BSA in PBS (see above) and then incubated for $1.5 \mathrm{~h}$ at room temperature with various concentrations of $\mathrm{mAb} 144, \mathrm{H}-3$ (isotype IgG2a) using hybridoma supernatant fluids diluted in blocking buffer (range 1/10-1/1000). The strips were then incubated with a $1 / 1000$ dilution of $\mathrm{mAb} 218, \mathrm{C}-5$ (isotype $\operatorname{IgM}$ ) followed by a biotinylated anti-mouse $\operatorname{IgM}$ antibody from a kit used for isotyping (Zymed Laboratories). Peroxidase-conjugated streptavidin was then added and antibody binding visualized as described above. Conversely, the inhibition of the binding of $\mathrm{mAb} 144, \mathrm{H}-3$ (IgG2a) by various concentrations of $\mathrm{mAb}$ $218, \mathrm{C}-5$ was examined by using a biotinylated anti-mouse IgG2a antibody. Controls included incubations of strips with the blocking buffer instead of the $\mathrm{mAb}$ used for inhibition. The specificity of the isotype specific antibodies was also checked in this assay.

Dot-blot assay. Heat-treated bacteria $\left(30 \mathrm{~min}\right.$ at $\left.60^{\circ} \mathrm{C}\right)$ from the stationary phase of growth were spotted onto nitrocellulose as previously described (Kolberg et al., 1992). Some experiments were also performed with live, exponential phase pneumococci (determined by optical density measurements during growth). The primary antibodies were applied in the 
form of diluted hybridoma supernatant fluids and bound $\mathrm{mAbs}$ were detected with peroxidase-conjugated anti-antibodies (see above).

Solubilization of bacterial proteins. Bacteria from the stationary phase of growth were harvested by centrifugation, washed three times in PBS and killed by heat-treatment at $100{ }^{\circ} \mathrm{C}$ for $5 \mathrm{~min}$. The suspension was then sonicated, and nucleic acids were precipitated by addition of ethanol at $4{ }^{\circ} \mathrm{C}$ to a concentration of $20 \%(\mathrm{v} / \mathrm{v})$. Proteins were precipitated by increasing the ethanol concentration to $80 \%$. The ethanol precipitations were omitted in later experiments. The bacteria were solubilized in $0.5 \%(\mathrm{w} / \mathrm{v})$ sodium deoxycholate (DOC) (Merck) in $0.05 \mathrm{M}$ Tris $/ \mathrm{HCl}$ buffer containing $2 \mathrm{mM}$ EDTA (pH 8.6) for about $1 \mathrm{~h}$ at room temperature. Nonsolubilized materials were removed by centrifugation $(10 \mathrm{~min}$, $4^{\circ} \mathrm{C}, 20000 \mathrm{~g}$ ).

Immunoaffinity purification of bacterial proteins and microsequencing. mAb $144, \mathrm{H}-3$ was purified from ascitic fluid by affinity chromatography on Protein A-Sepharose (Pharmacia Biotech). The mAb was then coupled to $\mathrm{CNBr}$-activated Sepharose according to the recommendations by the manufacturer (Pharmacia Biotech). The gel contained about $4 \mathrm{mg}$ protein $\mathrm{ml}^{-1}$. The DOC extract was first run through a Sepharose $6 \mathrm{~B}$ column to remove non-specifically binding proteins, and then through the column with immobilized $\mathrm{mAb}$ $144, \mathrm{H}-3$. After washing with the buffer used for application, bound proteins were eluted with $0.1 \mathrm{M}$ triethylamine in distilled water $(\mathrm{pH} \mathrm{11} \cdot 5)$. The fractions were neutralized with acetic acid, dialysed against $0.01 \mathrm{M}$ Tris/ $\mathrm{HCl}$ buffer $(\mathrm{pH} 8.6$ ) and concentrated by vacuum filtration. The eluted proteins were separated by SDS-PAGE using a comb for preparative electrophoresis and electroblotted onto a PVDF membrane (pore size $0.45 \mu \mathrm{m}$, Millipore). Rainbow molecular mass markers were used in the reference well of the comb. Strips were cut off and probed with $\mathrm{mAb} 144, \mathrm{H}-3$. The rest of the membrane was stained with $0.025 \%$ Coomassie brilliant blue in methanol. After destaining in $50 \%(\mathrm{v} / \mathrm{v})$ methanol, bands reacting with the $\mathrm{mAb}$ were identified by comparison with the molecular mass markers. The strips were incubated with $\mathrm{mAb}$ $144, \mathrm{H}-3$ and then cut out for N-terminal amino acid microsequencing. Automatic Edman degradation was performed on an Applied Biosystems model 477A equipped with an on-line 120A PTH amino acid analyser.

Sequence alignment. Searches in the swISS-PROT protein sequence databank (Bairoch \& Boeckmann, 1991) and sequence alignment were done using the Wisconsin Sequence Analyses Package (Devereux et al., 1984). Prediction of antigenic epitopes was determined according to Kolaskar \& Tongaonkar (1990) using the European Molecular Biology Network on-line EGCG-8.0 package.

\section{RESULTS}

mAb 144, $\mathrm{H}-3$ reacts with a $12 \mathrm{kDa}$ eubacterial protein and also with a $\mathbf{4 3} \mathrm{kDa}$ streptococcal protein in Western blotting

Dot-blotting showed that 60 different heat-treated pneumococcal strains representing all capsular types included in the 23-valent vaccine reacted with this antibody (isotype IgG2a) (data not shown). Live pneumococci did not react with mAb 144, H-3.

Thirty of the pneumococcal strains were also analysed by Western blotting against mAb 144,H-3. All showed (a)

(b)

$\begin{array}{llllllllllllllllll}1 & 2 & 3 & 4 & 5 & 6 & 7 & 8 & 9 & 1 & 2 & 3 & 4 & 5 & 6 & 7 & 8 & 9\end{array}$

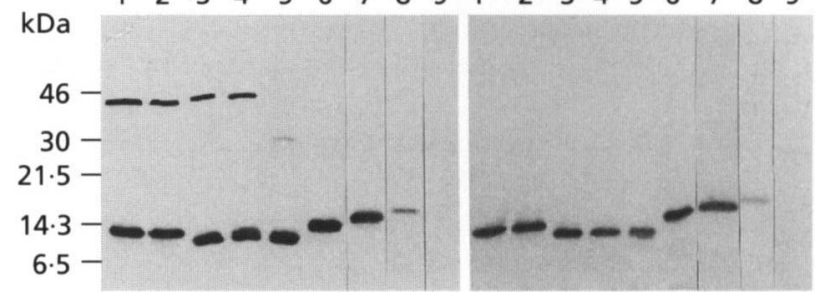

Fig. 1. Western blots with bacteria probed with mAb $144, \mathrm{H}-3$ (a) or 218,C-5 (b). Lanes 1 and 2, two different strains of Streptococcus pneumoniae; lane 3, Streptococcus mitis; lane 4, Streptococcus sanguis; lane 5, Escherichia coli; lane 6, Haemophilus influenzae; lane 7, Micrococcus luteus; lane 8, Mycobacterium bovis; lane 9, Archaeoglobus fulgidus.

two reactive bands, of 12 and $43 \mathrm{kDa}$ (Fig. 1). The hybridoma cells had been recloned and the clones examined in Western blotting to ensure that the cultures did not contain two hybridomas producing two antibodies of the same isotype directed against different proteins. The cross-reactivity of $\mathrm{mAb} 144, \mathrm{H}-3$ with bacteria other than pneumococci was investigated by Western blotting (Fig. 1, Table 1). For all the 12 examined streptococcal species, mAb 144,H-3 reacted with both the 12 and $43 \mathrm{kDa}$ proteins. In contrast, in the case of the other 15 non-streptococcal eubacterial species, both Gram-positive and Gram-negative, $\mathrm{mAb}$ $144, \mathrm{H}-3$ only reacted with the $12 \mathrm{kDa}$ protein by Western blotting (Table 1). The two examined mycobacterial species showed much weaker reactions than the other bacteria (M. bovis is shown in Fig. 1, lane 8). In addition to reacting with the $12 \mathrm{kDa}$ protein of $E$. coli, mAb 144,H-3 also showed a weak cross-reaction with a $30 \mathrm{kDa}$ protein (Fig. 1, lane 5). Some minor differences in the mobilities of the reactive proteins were seen between the analysed organisms (Fig. 1). The only archaeobacterium examined (Table 1) did not react with mAb 144,H-3 (Fig. 1, lane 9). The epitope on the $12 \mathrm{kDa}$ protein recognized by $\mathrm{mAb} 144, \mathrm{H}-3$ was expressed in all examined eubacteria, whereas the epitope on the $43 \mathrm{kDa}$ protein was common only to all the tested streptococci.

\section{Amino acid sequence similarities of eubacterial $12 \mathrm{kDa}$ protein with L7/L12 ribosomal proteins and of streptococcal $\mathbf{4 3} \mathrm{kDa}$ protein with elongation factor Ts}

Bacterial proteins from DOC extracts were purified by immunoaffinity chromatography with the mAb bound to $\mathrm{CNBr}$-Sepharose. The eluted proteins were run in preparative SDS-PAGE, and the separated proteins were electrotransferred to a PVDF membrane. In the case of S. pneumoniae strain 456/94 (type 6B), strips bearing the 12 and $43 \mathrm{kDa}$ proteins were cut off and the $\mathrm{N}$ terminal amino acid sequences of these proteins were determined. The $\mathrm{N}$-terminal amino acid sequence of the 
Table 1. Proteins from different organisms detected by mAb $144, \mathrm{H}-3$ in Western blots

\begin{tabular}{|c|c|c|}
\hline \multirow[t]{2}{*}{ Organisms/cells } & \multicolumn{2}{|c|}{ Western blotting reactivity } \\
\hline & $12 \mathrm{kDa}$ & $43 \mathrm{kDa}$ \\
\hline \multicolumn{3}{|l|}{ Eubacteria } \\
\hline \multicolumn{3}{|l|}{ Streptococci } \\
\hline S. pneumoniae $(n=30)$ & + & + \\
\hline S. suis type 8 SIS 14636 & + & + \\
\hline S. mitis $(n=3)$ & + & + \\
\hline S. bovis $971 / 92$ & + & + \\
\hline S. salivarius $56 / 93$ & + & + \\
\hline S. milleri $(n=2)$ & + & + \\
\hline S. sanguis $(n=3)$ & + & + \\
\hline S. pyogenes ATCC 12353 & + & + \\
\hline S. agalactiae $1010 / 90$ & + & + \\
\hline S. equisimilis C 74 & + & + \\
\hline S. mutans $604 / 92$ & + & + \\
\hline S. zooepidemicus 44/93 & + & + \\
\hline \multicolumn{3}{|l|}{ Other species } \\
\hline Staphylococcus aureus ATCC 12598 & + & $-*$ \\
\hline Haemophilus influenzae $(n=5)$ & + & - \\
\hline Neisseria meningitidis $(n=2)$ & + & - \\
\hline Escherichia coli U5/41 & + & - \\
\hline Salmonella typhimurium 1406 strain 9 & + & - \\
\hline Brucella melitensis $16 \mathrm{M}$ & + & - \\
\hline Actinobacillus actinomycetemcomitans ATCC 33384 & + & - \\
\hline Listeria monocytogenes 4 a $52-14$ & + & - \\
\hline Micrococcus luteus FH-Ba 2029 & + & - \\
\hline Bacillus subtilis ATCC 6633 & + & - \\
\hline Bacillus stearothermophilus ATCC 7953 & + & - \\
\hline Enterococcus faecalis ATCC 19433 & + & - \\
\hline Enterococcus faecium ATCC 19434 & + & - \\
\hline Mycobacterium bovis BCG & $+\dagger$ & - \\
\hline Mycobacterium leprae & $+t$ & - \\
\hline \multicolumn{3}{|l|}{ Archaeobacterium } \\
\hline Archaeoglobus fulgidus VC-16 & - & - \\
\hline \multicolumn{3}{|l|}{ Eukaryotic cells } \\
\hline Mouse splenocytes $(n=1)$ & - & - \\
\hline Human lymphocytes $(n=1)$ & - & - \\
\hline
\end{tabular}

* Some additional bands were seen in this region. They were also detected with mAbs against irrelevant antigens.

tWeaker reactions than for the other bacteria.

$12 \mathrm{kDa}$ protein from Neisseria meningitidis strain $44 / 76$ (group B) was also obtained.

These Western blot analyses and the protein staining of the PVDF membrane showed two additional bands corresponding to proteins of 25 and $50 \mathrm{kDa}$, respectively. These were assumed to be light and heavy chains from leakage of $\mathrm{mAb} 144, \mathrm{H}-3$ from the affinity column.

When the sequence of the first 42 amino acids of the $12 \mathrm{kDa}$ protein from $S$. pneumoniae strain $456 / 94$ was compared to sequences in the swISs-PROT databank, significant sequence similarity was found with bacterial ribosomal proteins. The identity in the first 42 residues was $86 \%$ to Bacillus subtilis ribosomal protein B-L9, which corresponds to $E$. coli ribosomal protein L7/L12 (Fig. 2). In contrast, in the case of the $12 \mathrm{kDa}$ protein of $N$. meningitidis, amino acid residues in positions $1-17$ were found to be identical in only two positions with the pneumococcal $12 \mathrm{kDa}$ protein (Fig. 2). However, the next three amino acids of the meningococcal protein (18-20) were identical to those of S. pneumoniae.

Comparison of the amino acid sequences of 16 eubacterial L7/L12 ribosomal proteins available in the swissPROT databank showed conserved sequences in several regions relative to the amino acid sequence of the 


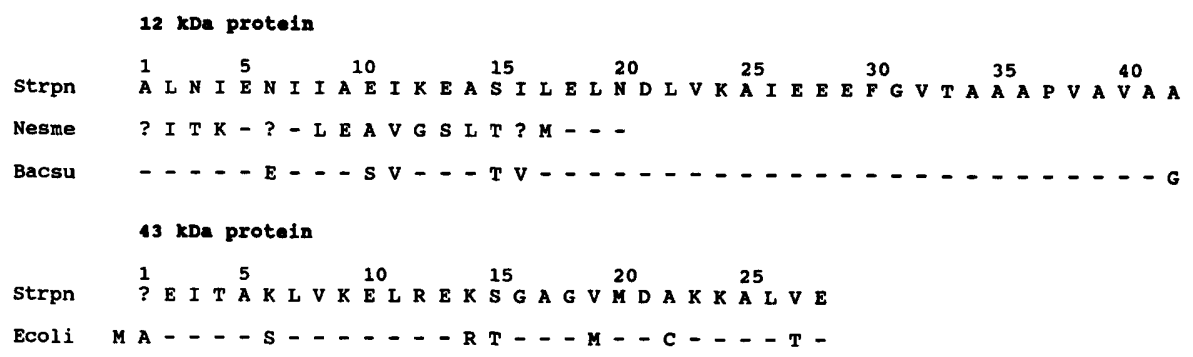

Fig. 2. Comparison of the $\mathrm{N}$-terminal amino acid sequences of Streptococcus pneumoniae (Strpn) 12 and $43 \mathrm{kDa}$ proteins from strain 456/94 and Neisseria meningitidis (Nesme) $12 \mathrm{kDa}$ protein from strain 44/76 with Bacillus subtilis (Bacsu) ribosomal protein B-L9, which corresponds to Escherichia coli L7/L12 (Itoh \& Wittmann-Liebold, 1978) and EF-Ts from E. coli (Ecoli) (An et al., 1981). The proteins were isolated from DOC extracts of the bacteria by affinity chromatography on a column with mAb 144, $\mathrm{H}-3$ bound to $\mathrm{CNBr}$-Sepharose. The eluted proteins were separated by SDS-PAGE and electrotransferred onto a PVDF membrane. A strip of the membrane was cut off and probed with mAb 144,H-3. The rest of the membrane was stained with Coomassie brilliant blue. Strips containing the bands with the 12 and $43 \mathrm{kDa}$ proteins were cut off and subjected to amino acid microsequencing. Blanks $(-)$ indicate amino acid residues identical to those of $S$. pneumoniae at the corresponding positions.

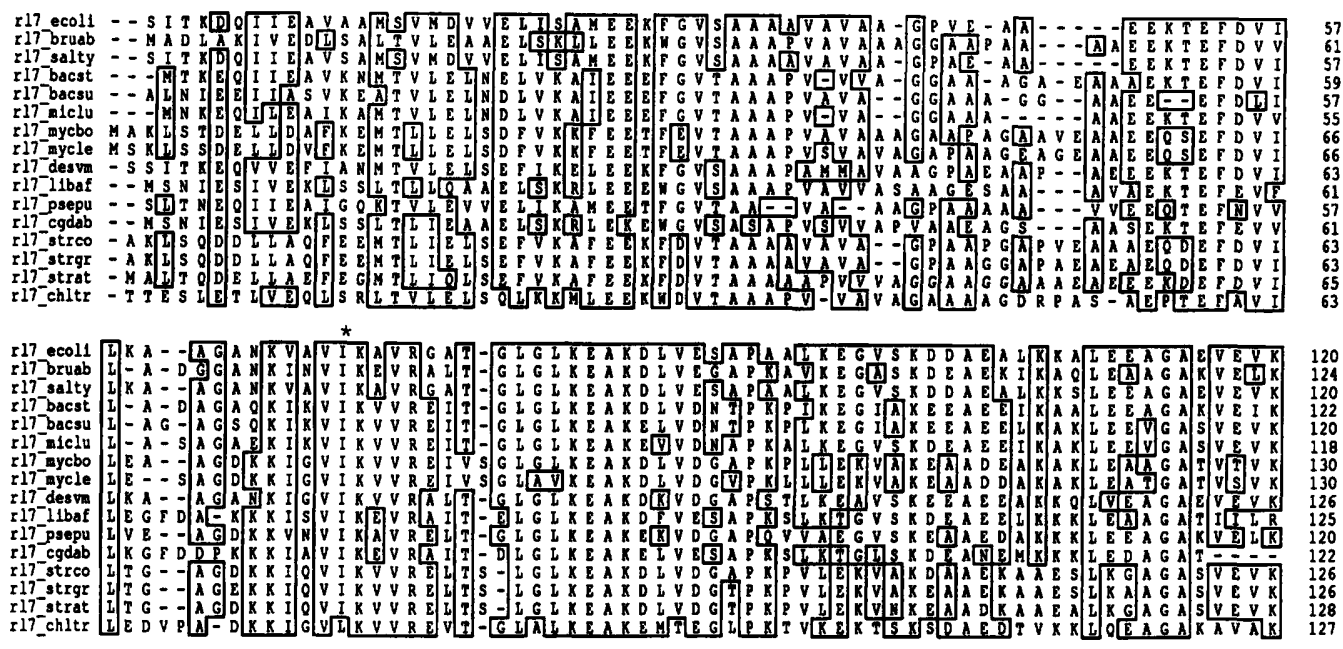

Fig. 3. Alignment of the amino acid sequences of $L 7 / L 12$ ribosomal proteins from Escherichia coli (r17_ecoli), Brucella abortus (r17_bruab), Salmonella typhimurium (r17_salty), Bacillus stearothermophilus (r17_bacst), Bacillus subtilis ( $r 17$ bacsu), Micrococcus luteus (r17_miclu), Mycobacterium bovis (r17_mycbo), Mycobacterium leprae (r17_mycle), Desulfovibrio vulgaris (r17_desvm), Liberobacter africanum (r17_libaf), Pseudomonas putida (r17_psepu), Citrus greening disease-associated bacterium-like organism (r17_cgdab), Streptomyces coelicolor (r17_strco), Streptomyces griseus (r17_ strgr), Streptomyces antibioticus (r17_strat) and Chlamydia trachomatis (r17_chltr). The amino acid sequences are from the SWISS-PROT databank (Bairoch \& Boeckmann, 1991). Proteins are numbered relative to r17_ecoli. Blanks $(-)$ represent gaps in alignment to obtain the best identity/similarity in the sequence. The asterisk indicates lle69.

L7/L12 ribosomal protein of E. coli (Fig. 3). Of these 16 eubacterial species, the first eight listed in Fig. 3 were included in the present study. All 16 sequences were analysed for antigenic epitopes using the predictive method of Kolaskar \& Tongaonkar (1990). The strongest common predicted epitope for all 16 of the L7/L12 amino acid sequences was observed in the consensus sequence comprising amino acid residues 65-73 of the E. coli ribosomal protein L7/L12 at and around residue Ile69.

The $\mathrm{N}$-terminal sequence of the $43 \mathrm{kDa}$ protein of pneumococcal strain $456 / 94$ reactive with mAb $144, \mathrm{H}-$ 3 is given in Fig. 2. A sequence identity of $78 \%$ with $E$. coli elongation factor Ts (EF-Ts) was found.

\section{mAb 218,C-5 reacts with ribosomal L7/L12 proteins, but not with the same epitope as $\mathrm{mAb} 144, \mathrm{H}-3$}

While characterizing $\mathrm{mAb} 144, \mathrm{H}-3$, a second $\mathrm{mAb}$ that bound the $12 \mathrm{kDa}$ protein was found. This was designated 218,C-5 (IgM). mAb 218,C-5, unlike mAb 144,H3 , did not react with the $43 \mathrm{kDa}$ pneumococcal protein with amino acid sequence identity to the $E$. coli EF-Ts (Fig. 1). However, the dot-blot patterns of the two mAbs against different Gram-positive and Gram-negative eubacteria were similar. To show that the epitopes for mAbs 144,H-3 and 218,C-5 were located on the same $12 \mathrm{kDa}$ protein, Western blotting was performed with pneumococcal proteins obtained by immunoaffinity chromatography with a mAb144,H-3-CNBr-Sepharose 
column. mAb 218,C-5 was also found to react with the $12 \mathrm{kDa}$ protein (data not shown).

The inhibition studies using nitrocellulose strips containing separated pneumococcal proteins showed that $\mathrm{mAb} 144, \mathrm{H}-3$ did not inhibit the binding of $\mathrm{mAb} 218$, C5. A weak inhibiton of the binding of $\mathrm{mAb} 144, \mathrm{H}-3$ was seen with the highest concentrations of $\mathrm{mAb} 218, \mathrm{C}-5$ (data not shown).

\section{DISCUSSION}

$\mathrm{N}$-terminal amino acid sequencing of the pneumococcal $12 \mathrm{kDa}$ protein reacting with $\mathrm{mAb} 144, \mathrm{H}-3$ showed a high degree of amino acid sequence identity with Bacillus subtilis ribosomal protein B-L9 (Fig. 2). The molecular mass of this protein is $12633 \mathrm{Da}$ (Itoh \& WittmannLiebold, 1978), which is in agreement with our estimation for the pneumococcal analogue. The $B$. subtilis B-L9 protein corresponds to $E$. coli ribosomal proteins L7/L12 (Itoh \& Wittmann-Liebold, 1978). The L7/L12 proteins are essential in bacterial ribosomes for proper functioning of several elongation factors involved in protein synthesis (for a review see Liljas, 1990). Ribosomal proteins L7/L12 are encoded by the same gene and differ only by acetylation of the $\mathrm{N}$-terminus of the L12 protein, which then becomes the L7 protein (Terhorst et al., 1973).

Data on the nucleotide sequences of ribosomal protein genes from bacteria, or on the amino acid sequences of ribosomal proteins, are limited to a few microorganisms. Ribosomal proteins belonging to the L7/L12 family share strong amino acid sequence identity within the eubacteria (Liao \& Dennis, 1994). Alignment of the complete amino acid sequences available for L7/L12 ribosomal proteins from 16 different bacterial species in the swiss-PROT databank is shown in Fig. 3. The Cterminus contains the highly conserved regions, whereas there is less sequence conservation at the $\mathrm{N}$-terminus. Our finding that the amino acid residues of the $N$. meningitidis $12 \mathrm{kDa}$ protein in this region were quite different from those of the pneumococcal $12 \mathrm{kDa}$ protein support this observation. Moreover, even though no sequences for the $S$. pneumoniae L7/L12 proteins are available, the fact that the three amino acids identified at amino acid positions 18-20 were identical to the pneumococcal protein suggests possible homology between the N. meningitidis and S. pneumoniae proteins.

The mAb 144,H-3 seems to detect a conserved epitope within eubacterial L7/L12 proteins. When the available amino acid sequences were analysed for antigenicity, several regions displayed strong antigenic properties. The region around residue Ile69, which in Chlamydia trachomatis is replaced by Leu (Fig. 3), gave the highest values, indicating that the epitope is most probably located within this helix.

The L7/L12 proteins in M. bovis and M. leprae showed much weaker Western blot reactivity than the other eubacteria. The sequence comparison showed sequence identity in the putative epitope. It might be that these slowly growing organisms contain less ribosomal proteins than the other eubacteria.

The only examined archaeobacterium showed a lack of reactivity with the mAbs. This was expected because the archaeal equivalent $\mathrm{L} 7 / \mathrm{L} 12$ proteins are more closely related in both amino acid sequence and size to the human P-proteins than to their $E$. coli counterparts (Casiano \& Traut, 1994).

A second $\mathrm{mAb}$, designated $218, \mathrm{C}-5$, also recognized the L7/L12 protein. This mAb did not cross-react with the streptococcal $43 \mathrm{kDa}$ protein, indicating interaction with different epitopes. This was supported by competition studies. The epitopes are most likely closely located because the $\operatorname{IgM}$ antibody (218,C-5) weakly inhibited the binding of the IgG2a antibody $(144, \mathrm{H}-3)$.

$\mathrm{N}$-terminal sequencing of the $43 \mathrm{kDa}$ protein from $S$. pneumoniae reacting with $\mathrm{mAb} 144, \mathrm{H}-3$ showed $78 \%$ identity with E. coli EF-Ts. E. coli EF-Ts contains 283 amino acid residues (An et al., 1981), giving a molecular mass of about $30 \mathrm{kDa}$. Western blots performed with $E$. coli showed a very faint band in the $30 \mathrm{kDa}$ region that could be EF-Ts (Fig. 1). A shift in molecular mass to $43 \mathrm{kDa}$ was found for the strongly reacting analogue in all examined strains of $S$. pneumoniae and other streptococci. There are no reports on amino acid sequences for eubacterial EF-Ts proteins other than $E$. coli. However, the complete amino acid sequence of Thermus thermophilus EF-Ts was recently reported by Blank et al. (1996). EF-Ts from T. thermophilus is considerably shorter than EF-Ts from $E$. coli, differing in size by 86 amino acids.

Our work with mAb $144, \mathrm{H}-3$ indicates similarities between ribosomal protein L7/L12 and streptococcal ET-Ts, a factor which is essential for the elongation of the polypeptide chain during protein synthesis. The two proteins recognized by mAb $144, \mathrm{H}-3$ are both components of the translational machinery and should normally be inaccessible to antibodies. This is consistent with our finding that the antigens in living pneumococci were not recognized by $\mathrm{mAb} 144, \mathrm{H}-3$ in the dot-blot assay.

It is difficult to speculate about the relationship between the conserved antigenic determinant on the L7/L12 protein and the cross-reacting epitope on streptococcal EF-Ts because we do not know the amino acid sequence of the streptococcal protein.

The mAb 144,H-3 may be a potentially valuable reagent in studying the streptococcal EF-Ts. The data from the bacteria analysed so far indicate that this epitope on EFTs from streptococci might represent a taxonomic marker. Interestingly, in the case of the two enterococcal species examined, mAb $144, \mathrm{H}-3$ did not react with the $43 \mathrm{kDa}$ protein. The enterococci were formerly classified as streptococci, but the genus Enterococcus is now generally accepted (Facklam \& Sahm, 1995). Our observations appear to support this new classification. 
The immunological importance of ribosomal preparations of $M$. bovis and other intracellular micro-organisms such as Brucella abortus has been emphasized by different investigators, and the $\mathrm{L} 7 / \mathrm{L} 12$ proteins have been identified as important antigens (Tantimavanich $e t$ al., 1993; Bachrach et al., 1994; Oliveira et al., 1994). Ribosomal preparations have been used as vaccines in experimental animals (Normier et al., 1992) and have also been examined for use as vaccines for humans (Michel et al., 1978; Béné et al., 1993). The mAbs described here could possibly be useful tools in the characterization and standardization of ribosomal vaccines.

\section{ACKNOWLEDGEMENTS}

Anne Lise Heistø, Gro Lermark, Torunn Marigård and Gunnhild Rødal provided excellent technical assistance. Part of this work was financed by the Norwegian Research Council.

\section{REFERENCES}

An, G., Bendiak, D. S., Mamelak, L. A. \& Friesen, J. D. (1981). Organization and nucleotide sequence of a new ribosomal operon in Escherichia coli containing the genes for ribosomal protein S2 and elongation factor Ts. Nucleic Acids Res 9, 4163-4172.

Bachrach, G., Banal, M., Bardenstein, S., Hoida, G., Genizi, A. \& Bercovier, H. (1994). Brucella ribosomal protein L7/L12 is a major component in the antigenicity of brucellin INRA for delayed-type hypersensitivity in Brucella-sensitized guinea pigs. Infect Immun 62, 5361-5366.

Bairoch, A. \& Boeckmann, B. (1991). The SWISS-PROT protein sequence data bank. Nucleic Acids Res 19, 2247-2249.

Béné, M. C., Kahl, L., Perruchet, A. M., Hermes, H., Mósges, M., Normier, G., Binz, H. \& Faure, G. C. (1993). Bacterial lysates and ribosomes as inducers of specific immune responses: a comparative study. Scand J Immunol 38, 496-498.

Blank, J., Nock, S., Kreutzer, R. \& Sprinzl, M. (1996). Elongation factor Ts from Thermus thermophilus. Overproduction in Escherichia coli, quaternary structure and interaction with elongation factor Tu. Eur J Biochem 236, 222-227.

Casiano, C. A. \& Traut, R. R. (1994). Stoichiometry of Sulfolobus ribosomal protein L12e in 50S subunits determined by quantification of immunoblots. Biochem Biophys Res Commun 203, 1140-1145.

Devereux, J., Haeberli, P. \& Smithies, O. (1984). A comprehensive set of sequence analysis programs for the VAX. Nucleic Acids Res 12, 387-395.

Facklam, R. R. \& Sahm, D. F. (1995). Enterococcus. In Manual of Clinical Microbiology, 6th edn, pp. 308-314. Edited by P. R. Murray, E. J. Baron, M. A. Pfaller, F. C. Tenover \& R. H. Yother. Washington, DC: American Society for Microbiology.

Fazekas de St Groth, S. \& Scheidegger, D. (1980). Production of monoclonal antibodies: strategy and tactics. J Immunol Methods 35, 1-21.

Henrichsen, J. (1995). Six newly recognized types of Streptococcus pneumoniae. J Clin Microbiol 33, 2759-2762.

Itoh, T. \& Wittmann-Liebold, B. (1978). The primary structure of Bacillus subtilis acid ribosomal protein B-L9 and its comparison with Escherichia coli proteins L7/L12. FEBS Lett 96, 392-394.
Kolaskar, A. S. \& Tongaonkar, P. C. (1990). A semi-empirical method for prediction of antigenic determinants on protein antigens. FEBS Lett 276, 172-174.

Kolberg, J., Aaberge, I. S., Jantzen, E., Løvik, M., Lermark, G. \& Steen, T. (1992). Murine monoclonal antibodies against pneumococcal capsular polysaccharide types $4,8,22 \mathrm{~F}$ and $19 \mathrm{~A} / 19 \mathrm{~F}$. APMIS 100, 91-94.

Laemmli, U. K. (1970). Cleavage of structural proteins during the assembly of the head of bacteriophage T4. Nature 227, 680-685.

Lane, R. D. (1985). A short-duration polyethylene glycol fusion technique for increasing production of monoclonal antibodysecreting hybridomas. J Immunol Methods 81, 223-228.

Liao, D. \& Dennis, P. P. (1994). Molecular phylogenies based on ribosomal protein L11, L1, L10, and L12 sequences. J Mol Evol 38, 405-419.

Liljas, A. (1990). Some structural aspects of elongation. In The Ribosome: Structure, Function \& Evolution, pp. 309-317. Edited by W. E. Hill, A. Dahlberg, R. A. Garrett, P. B. Moore, D. Schlessinger \& J. R. Warner. Washington, DC: American Society for Microbiology.

Lund, E. \& Henrichsen, J. (1978). Laboratory diagnosis, serology and epidemiology of Streptococcus pneumoniae. Methods Microbiol 12, 241-262.

MCDaniel, L. S. \& Briles, D. E. (1986). Monoclonal antibodies against surface components of Streptococcus pneumoniae. In Monoclonal Antibodies Against Bacteria, pp. 143-164. Edited by A. J. L. Macario \& E. C. de Macario. Orlando, FL: Academic Press.

Michel, F. B., Dussourd d'Hinterland, L., Bousquet, J., Pinel, A. M. \& Normier, G. (1978). Immuno-stimulation by a ribosomal vaccine associated with bacterial cell wall adjuvant in humans. Infect Immun 20, 760-769.

Normier, G., Pinel, A. M., Dussourd d'Hinterland, L., Wigzell, H. \& Binz, H. (1992). Ribosomes as carriers for antigenic determinants of the surface of micro-organisms. Dev Biol Stand 77, 79-85.

Oliveira, S. C., Zhu, Y. \& Splitter, G. A. (1994). Recombinant L7/L12 ribosomal protein and $\gamma$-irradiated Brucella abortus induce a T-helper 1 subset response from murine CD4 $+\mathrm{T}$ cells. Immunology 83, 659-664.

Sommer, A., Etchison, J. R., Gavino, G., Zecherle, N., Casiano, C. \& Traut, R. R. (1985). Preparation and characterization of two monoclonal antibodies against different epitopes in Escherichia coli ribosomal protein L7/L12.J Biol Chem 260, 6522-6527.

Steiter, K. O. (1988). Archaeoglobus fulgidus gen. nov.: a new taxon of extremely thermophilic archaebacteria. Syst Appl Microbiol 10, 172-173.

Tantimavanich, S., Nagai, S., Nomaguchi, H., Kinomoto, M., Ohara, N. \& Yamada, T. (1993). Immunological properties of ribosomal proteins from Mycobacterium bovis BCG. Infect Immun 61, 4005-4007.

Terhorst, C., Moller, W., Laursen, R. \& Wittmann-Liebold, B. (1973). The primary structure of an acidic protein from 50-S ribosomes of Escherichia coli which is involved in GTP hydrolysis dependent on elongation factors $G$ and T. Eur J Biochem 34, 138-152.

Tuomanen, E. I., Austrian, R. \& Masure, H. R. (1995). Pathogenesis of pneumococcal infection. $N$ Eng $J$ Med 332, 1280-1284.

Received 22 April 1996; revised 22 August 1996; accepted 11 September 1996. 